\title{
STATUS OHI-S DAN KESEHATAN GINGIVA TERHADAP PERCAYA DIRI PADA REMAJA
}

\author{
Erwin $^{1}$, Suhikma Sofyan², Andi Nur Asmayanti ${ }^{3}$ \\ ${ }^{123}$ Akademi Kesehatan Gigi Bina Husada Kendari, Sulawesi Tenggara, Indonesia \\ Coressponding Author: erwin7tgm@gmail.com
}

\begin{abstract}
ABSTRAK
OHI-S adalah suatu keadaan kebersihan gigi dan mulut yang diukur dari skor debris dan calculus gigi seseorang. Gingiva merupakan bagian dari jaringan periodontal yang paling luar. Kepercayaan diri adalah sikap positif seseorang yang memampukan dirinya untuk mengembangkan penilaian positif baik terhadap diri sendiri maupun lingkungan. Tujuan Penelitian untuk mengetahui hubungan status OHI-S dan kesehatan gingiva terhadap percaya diri pada remaja kelas VII di SMPN 2 Unaaha. Jenis penelitian analitik korelatif dengan pendekatan cross sectinal. Teknik pengumpulan data yaitu kuisioner dan pemeriksaan. Sampel berjumlah 103 orang.Teknik analisa dengan program SPSS dan uji statistik menggunakan chi square. Hasil uji hubungan status OHI-S terhadap percaya diri dengan uji analisis chi square. Nilai $\rho$-value $=0,00<\alpha=0,05$ dengan demikian $\mathrm{H}_{0}$ ditolak dan $\mathrm{H}_{1}$ diterima sehingga ada hubungan status OHI-S terhadap percaya diri pada remaja kelas VII di SMPN 2 Unaaha. Hasil uji hubungan kesehatan gingiva terhadap percaya diri dengan uji analisis chi squarenilai $\rho$-value $=0.00<\alpha=0,05$ dengan demikian $\mathrm{H}_{0}$ ditolak dan $\mathrm{H}_{1}$ diterima sehingga ada hubungan status kesehatan gingiva terhadap percaya diri pada remaja kelas VII di SMPN 2 Unaaha.
\end{abstract}

Kata Kunci : OHI-S, Kesehatan Gingiva,
Percaya Diri

\section{ABSTRACT}

OHI-S is a state of oral and dental hygiene measured by a debris score and calculus of a person's teeth. Gingiva is part of the outer periodontal tissue. Selfconfidence is a positive attitude of someone who enables him to develop a positive assessment of himself and his environment. The aim of the study was to determine the relationship of OHI-S status and gingival health to self-confidence in class VII adolescents at Unaaha 2 Public High School. Type of correlative analytic research with cross sectional approach. Data collection techniques are questionnaire and examination. The sample amounted to 103 people. Analysis techniques with the SPSS program and statistical tests using chi square. The test results of the relationship of OHI-S status to confidence with the chi square analysis test. The value of $\rho$-value $=0.00<\alpha=0.05$ thus $H_{0}$ is rejected and $H_{1}$ is accepted so that there is a relationship between the status of $\mathrm{OHI}-\mathrm{S}$ and self confidence in adolescents of class VII at Unaaha Public High School 2. The test results on the relationship of gingival health to self-confidence with the chi-square analysis value $\rho$-value $=0.00<\alpha=0.05$ thus $\mathrm{HO}$ is rejected and $\mathrm{Hl}$ is accepted so that there is a relationship between gingival health status and confidence in class VII youth at Unaaha 2 Public High School.

Keywords: OHI-S, gingival health, self- Confidence

\section{PENDAHULUAN}

OHI-S merupakan indeks yang mengukur kebersihan gigi dan mulut salah satu indikator dalam pengukuran OHI-S adalah tingkat debris index, dan calculus index,dimana evaluasinya terhadap perkembangan debris dancalculus tersebut akan berpengaruh terhadap status kesehatan jaringan penyangga gigi (Putri, 2010).

Gingivitis merupakan penyakit periodontal stadium awal yang berupa peradangan pada gingiva, termasuk penyakit umum yang sering ditemukan pada jaringan mulut. Gingivitis yang ringan pada umumnya tidak segera mendapat perhatian 
karena tidak menimbulkan rasa sakit atau gangguan fungsi, akan tetapi jika keadaan dibiarkan, gingivitis dapat menjadi bentuk yang destruktif. Prevalensi gingivitis dapat berkurang dengan bertambah baiknya status oral hygiene, flour yang memadai, diet yang baik, perawatan pemeliharaan kesehatan dan kebiasaan hidup. Prevalensi gingivitis yang dijumpai adalah tertinggi $(92,7 \%)$ dengan distribusi gingivitis ringan $58,1 \%$, gingivitis sedang $32,3 \%$, dan gingivitis berat $2,4 \%$ sedangkan anak yang bebas dari gingivitis hanya $7,3 \%$, berdasarkan jenis kelamin secara umum presentase gingivitis pada anak laki-laki sedikit lebih tinggi dibandingkan dengan anak perempuan (Irma, dkk, 2013).

Kepercayaandiri seseseorang sangat dipengaruhi oleh masa perkembangan yang sedang dilaluinya terutama bagi remaja, kepercayaan diri ini akan mudah berubah. Siswa SMP tergolong usia remaja awal yang berada pada masa puber. Masa puber yaitu suatu tahap dalam perkembangan dimana terjadi kematangan alat-alat seksual dan tercapai kemampuan reproduksi. Remaja yang tadinya sangat yakin pada diri sendiri, sekarang menjadi kurang percaya diri dan takut akan kegagalan. Hal ini terjadi karena daya tahan fisik menurun dan adanya kritik yang datang dari orang tua dan teman-teman (Angelis, 2005)

\section{METODE PENELITIAN}

Jenis penelitian yang digunakan adalah analitik korelatif dengan pendekatan cross sectional Pengambilan sampel ini menggunakan teknikpurposive sampling yaitu pemeriksaan sampel dengan menetukan kriteria khusus kepada sampel sesuai pertimbangan peneliti (Prasetyo, Bambang, 2005)

Adapun ciri-ciri sampel tersebut yaitu :

Kriteria Inklusi :

1. Masih ada gigi index yang akan diperiksa

2. Tidak memakai kawat gigi

3. Bersedia menjadi responden

Kriteria Ekslusi :

1. Memakai gigi tiruan atau kawat gigi

2. Tidak bersedia menjadi responden

Sampel sebanyak 103 orang dari semua yang memenuhi kriteria inklusi.

Instrument Penelitian ini adalah Probe sonde, Pinset, Miror mouth, Excavator, Sonde, Alkohol 70\%, Nier bekken , Kapas , Handscoon, Masker, Kuisioner

Analisa data pada penelitian ini menggunakan komputer dengan program excel, SPSS (Statisttical Product and Service Solution) dan uji chi square.

\section{HASIL DAN PEMBAHASAN}

Penelitian ini dilakukan di SMPN 2 Unaaha pada tanggal 25 Mei 2016 sampai 27 Mei 2016 denganjudul " hubungan status OHI-S dan kesehatan gingiva terhadap percaya diri pada remaja kelas VII di SMPN 2 Unaaha" dengan siswa yang menjadi responden adalah 103 orang. Penelitian ini bersifat survei analitik cara pengambilan sampel adalah teknik purposive sampling. Penelitian ini bertujan untuk mengetahui hubungan status OHI-S dan kesehatan gingiva terhadap percaya diri pada remaja kelas VII di SMPN 2 Unaaha. 
Tabel 1

Hubungan status OHI-S terhadap percaya diri pada remaja kelas VII di SMPN 2 Unaaha

\begin{tabular}{|c|c|c|c|c|c|c|c|c|}
\hline \multirow{3}{*}{ No } & \multirow{3}{*}{$\begin{array}{c}\text { Kriteria } \\
\text { OHI-S }\end{array}$} & \multicolumn{4}{|c|}{ Kategori Percaya diri } & \multirow{2}{*}{\multicolumn{2}{|c|}{ Jumlah }} & \multirow{3}{*}{$\begin{array}{c}\mathrm{X}_{\text {hit }} \\
(\rho \text {-value })\end{array}$} \\
\hline & & \multicolumn{2}{|c|}{$\begin{array}{c}\text { Percaya diri } \\
\text { Tinggi }\end{array}$} & \multicolumn{2}{|c|}{$\begin{array}{l}\text { Percaya diri } \\
\text { sedang }\end{array}$} & & & \\
\hline & & Jumlah & $\%$ & Jumlah & $\%$ & $\mathrm{n}$ & $\%$ & \\
\hline 1 & Baik & 37 & 35,9 & 4 & 3,9 & 41 & 39,8 & $75.785^{\mathrm{a}}$ \\
\hline 2 & Sedang & 3 & 2,9 & 59 & 57,3 & 62 & 60,2 & $(0,000)$ \\
\hline & Uumlah & 40 & 38,8 & 63 & 61,2 & 103 & 100 & \\
\hline
\end{tabular}

Sumber : Data Primer Tahun 2016

Tabel 1, menunjukkan bahwa pada sampel dengan kriteria OHI-S baik paling banyak ditemui kategori percaya diri tinggi sebanyak 37orang $(35,9 \%)$ dan pada sampel dengan kriteria O-HIS sedang paling banyak ditemui kategori percaya diri sedang sebanyak 59 orang $(57,3 \%)$. Berdasarkan uji analisis dengan menggunakan uji chi squarediperoleh hasil $\rho$-value $<$ dari $\alpha$ hasil $\rho$ value $=0.000<\alpha=0,05$ dengan demikian $\mathrm{H}_{0}$ ditolak dan $\mathrm{H}_{1}$ diterima sehingga ada hubungan status OHI-S terhadap percaya diri pada remaja kelas VII di SMPN 2 Unaaha Kecamatan Unaaha Kabupaten Konawe.

Tabel 2

Hubungan status kesehatan gingiva terhadap percaya diri pada remaja kelas VII di SMPN 2 Unaaha

\begin{tabular}{|c|c|c|c|c|c|c|c|c|}
\hline \multirow{3}{*}{ No } & \multirow{3}{*}{$\begin{array}{l}\text { Kriteria Gingiva } \\
\text { Index }\end{array}$} & \multicolumn{4}{|c|}{ Kategori percaya diri } & \multirow{2}{*}{\multicolumn{2}{|c|}{ Jumlah }} & \multirow{3}{*}{$\begin{array}{c}\mathrm{X}_{\text {hit }} \\
(\rho \text {-value })\end{array}$} \\
\hline & & \multicolumn{2}{|c|}{ Tinggi } & \multicolumn{2}{|c|}{ Sedang } & & & \\
\hline & & Jumlah & $\%$ & Jumlah & $\%$ & $\mathrm{n}$ & $\%$ & \\
\hline 1 & Sehat & 35 & 34,0 & 1 & 1,0 & 36 & 35,0 & \multirow{4}{*}{$\begin{array}{r}79.806^{\mathrm{a}} \\
-(0,000)\end{array}$} \\
\hline 2 & Peradangan Ringan & 5 & 4,9 & 49 & 47,6 & 54 & 52,4 & \\
\hline 3 & Peradangan sedang & 0 & 0 & 13 & 12,6 & 13 & 12,6 & \\
\hline & Jumlah & 40 & 38,8 & 63 & 61.2 & 103 & 100 & \\
\hline
\end{tabular}

Sumber : Data Primer Tahun 2016

Tabel 2 menunjukkan bahwa pada sampel dengan kriteria gingiva sehat paling banyak ditemui kategori percaya diri tinggi sebanyak 35 orang (34,0\%), pada sampel dengan kriteria peradangan ringan paling banyak ditemui kategori percaya diri sedang sebanyak 49 orang $(47,6 \%)$ dan pada sampel dengan kriteria gingiva peradangan sedang paling banyak ditemui kategori percaya diri sedang sebanyak 13 orang $(12,6 \%)$. 
Berdasarkan uji analisis dengan menggunakan uji chi square diperoleh hasil $\rho$-value $<$ dari $\alpha$ hasil $\rho$-value $=0.000<\alpha=0,05$ dengan demikian $\mathrm{H}_{0}$ ditolak dan $\mathrm{H}_{1}$ diterima sehingga ada hubungan status kesehatan gingiva terhadap percaya diri pada remaja kelas VII di SMPN 2 Unaaha Kecamatan Unaaha Kabupaten Konawe.

Berdasarkan tabel 1 menunjukkan bahwa pada sampel yang kriteria OHI-S baik dengan kriteria OHI-S sedang dengan kriteria percaya diri sedang sebanyak 59 orang $(57,7 \%)$.

Hasil analisa statistik hubungan status OHI-S terhadap percaya diripada remaja kelas VII di SMPN 2 Unaaha diperoleh nilai $\rho$-value $=0.000<\alpha=0,05$ dengan demikian $\mathrm{H}_{1}$ diterima dan $\mathrm{H}_{0}$ ditolak sehingga ada hubungan status OHI-S terhadap percaya diri pada remaja kelas VII di SMPN 2 Unaaha. Astrid M. Lesar (2015) menyatakan hampir keseluruhan Siswa Sekolah Menengah Pertama (SMP) berusia diantara 13 sampai 14 tahun, serta prevalensi kebersihan gigi dan mulut rata-rata berada pada kategori sedang sebesar $45 \%$. Pada penelitian yang dilakukan oleh Devinta Indariana Sari (2012) di Shelter Kuwang Argomulyo Cangkringan Sleman Yogyakarta masalah personal hygiene salah satunya masalah kesehatan gigi dan mulut sebanyak $32 \%$ mengalami kesehatan gigi dan mulut kurang baik. Personal hygiene merupakan tindakan seseorang memelihara kebersihan diri, memperbaiki personal hygiene yang kurang, mencegah penyakit, menciptakan keindahan, dan meningkatkan rasa percaya diri.
Berdasarkan tabel 2 menunjukkan bahwa pada sampel yang memiliki status kesehatan gingiva dengan kriteria gingiva index peradangan ringan dengan kategori percaya diri sedang berjumlah 49 oang $(47,6)$ dan responden dengan kriteria gingiva index sehat terhadap percaya diri tinggi 35 orang (34,0\%). Hasil analisa statistik hubungan status kesehatan gingiva terhadap percaya diri pada remaja kelas VII di SMPN 2 Unaaha diperoleh nilai $\rho$ value $=0.000<\alpha=0,05$ dengan demikian $\mathrm{H}_{1}$ diterima dan $\mathrm{H}_{0}$ ditolak sehingga ada hubungan status kesehatan gingiva terhadap percaya diri pada remaja kelas VII di SMPN 2 Unaaha.

\section{KESIMPULAN}

Berdasarkan hasil dari pembahasan, dapat disimpulkan bahwa :

1. Ada hubungan status O-HIS dan kesehatan gingiva terhadap percaya diri pada remaja kelas VII di SMPN 2 Unaaha Kecamatan Unaaha Kabupaten Konawe.

2. Tingkat kepercayaan diri pada remaja kelas VII di SMPN 2 Unaaha Kecamatan Unaaha Kabupaten Konawe paling tinggi kategori percaya diri sedang 63 orang $(61,2 \%)$.

3. Status O-HIS pada remaja kelas VII di SMPN 2 Unaaha Kecamatan Unaaha Kabupaten Konawe paling banyak dengan kriteria O-HIS sedang 62 orang $(60,2 \%)$.

4. Status kesehatan gingivapada remaja kelas VII di SMPN 2 Unaaha Kecamatan Unaaha Kabupaten Konawe paling banyak dengan kriteria peradangan ringan berjumlah 54 orang $(52,4 \%)$. 


\section{DAFTAR PUSTAKA}

Angelis, Barbara D. 2005. Confidence (Percaya Diri) Sumber Sukses dan Kemandirian. Jakarta : PT Gramedia Pustaka Umum

Astrid M. Lesar. 2015.Gambaran Status Kebersihan Gigi Dan Mulut Serta Status Gingiva Pada Anak Remaja Di SMP Advent Watulaney Kabupaten Minahasa.(Jurnal e-GiGi.)Vol 3. 2. Fakultas kedokteran Samratulangi: Manado Available form URL: 28 Maret 2016

Chandra, B. 2008. Metedologi Penelitian Kesehatan. EGC :Jakarta Grafindo Persada:jakarta

Herijulianti Eliza, et.all. 2011. Ilmu Pencegahan Penyakit Jaringan Keras dan Jaringan Pendukung Gigi.EGC:Jakarta

Hiranya Putri, Megananda. 2010. Ilmu Pencegahan Penyakit Jaringan Keras dan Jaringan Pendukung Gigi.EGC:Jakarta

Irma, dkk, 2013. Penyakit gigi dan THT, Nuhamedika:Jakarta

Notoatmodjo, S. 2007,Promosi Kesehatan dan Ilmu Perilaku,Rineka Cipta: Jakarta

Nurjannah, drg. Neneng, et.all (2010) “Ilmu Pencegahan Penyakit Jaringan Keras Dan Jaringan Pendukung Gigi” .EGC: Jakarta

Prasetyo, Bambang. 2005. Metodologi penelitian kuantitatif. PT. Raja Grafindo Persada: Jakarta

Soetjiningsih. 2007. Tumbuh kembang remaja dan permasalahannya.cv. Sagung seto: jakarta

Veny Adilia. 2013. Murid perempuan dan Murid laki-laki. 21 Agustus 2013 $\mathrm{http} / /$ permalink to murid perempuan dan murid laki-laki. Akses (25 juli 2016) 